\title{
Foreign Direct Investment, Sovereign Debt and Growth: Evidence for the Euro Area
}

\author{
Ai-Lian Tan ${ }^{1 *}$, Normaz Wana Ismail ${ }^{2}$ \\ ${ }^{1}$ Lecturer, Department of Economics, Faculty of Business and Finance, Universiti Tunku Abdul Rahman; Perak, MALAYSIA \\ ${ }^{2}$ Associate Professor, Department of Economics, Marketing and Trade Laboratory, Faculty of Economics \& Management, Universiti Putra \\ Malaysia; Serdang, MALAYSIA \\ $\&$ \\ Deputy Director, Agricultural Production, Institute of Agricultural and Food Policy Studies; Universiti Putra Malaysia; Serdang, \\ MALAYSIA
}

*E-mail for correspondence: tanal@utar.edu.my

Cell Phone: +016-7272386

Received: Jun 2, 2015;

Accepted: Jun 21, 2015;

Published: Jul 24, 2015

Source of Support: Nil

No Conflict of Interest: Declared

\begin{abstract}
In light of the global financial crisis, an extensive implementation of fiscal stimulus packages has triggered an enormous soared of public debt in Europe. While grappling with this albatross, the high debt level has aroused the paramount interest of this study casts doubt on the role of sovereign debt towards the linkage between FDI and economic growth. To this end, this study aims to assess the effects of debt on growth through the channel of FDI in European countries by applying Pooled Mean Group (PMG) estimation. The empirical findings, by and large, suggest that a lower growth performance is evident with the association of high government debt through foreign investment. In a nutshell, over borrowing of public finance would crowd out private investment and hence stifle economic growth.
\end{abstract}

Keywords: FDI; global financial crisis; sovereign debt; economic growth JEL Classifications Code: F21, F34, F43, G01

\section{INTRODUCTION}

In economic literature, investments are reckoned as a prevalent and powerful instrument in facilitating growth process. In Europe, FDI has been one of the crucial parts of policy in enhancing productivity and strengthening the association between European and the rest of world economy (Bevan and Estrin, 2004 and Roberts et al. 2008). Complementary trade, FDI generates a deeper phase of association between economies in European and nonEuropean countries through capital movement. According to Di Mauro (1999), FDI is a leading edge of globalization process in European continent since foreign firms have enhanced the efficiency of production and encouraged European economy to promote its products more broadly in international markets. Hence, foreign investment creates direct, stable and long-lasting links between European and world economy through the accession in new markets for high value-added products and services (Bevan and Estrin, 2004).

Germany, for instance, the largest national economy in the European continent with a high degree of opening market and stable political system, has attracted export-oriented foreign companies into the country (Jost, 2010). The presence of these foreign companies has erected production facilities and distribution in Germany. With this taken place, FDI has contributed to growth acceleration and foster integration process of Germany into the global economy. In addition to Germany, the inflows of foreign investment have also been a driving force in other peripheral European countries to be integrated into worldwide context through financial liberalization (OECD, 1994a and OECD, 1994b).

Nevertheless, a strand of scholars in recent years has posited that FDI is conducive to economic growth with the condition of host countries' absorptive capacity (Hansen and Rand, 2006; Alguacil et al., 2011 and Liu and Qiu, 2014). For instance, Yao and Wei (2007) and Alfaro et al. (2010) emphasize that the positive externalities driven by foreign investment would benefit recipient countries through the transmission of novel technology, yet provided that host countries have realized a minimum threshold level of human capital and financial development. In this respect, the incident of financial turmoil in the past decade has shed lighted the concern on the absorptive capacity of European countries in the context of their macroeconomic environment.

The evolution of banking crisis into financial and debt crises in 2008-2010 are an anecdotal evidence of the 
tragedy in European countries. The advent of the subprime mortgage crisis in the United States (U.S) has triggered the instability of financial institutions and developed into financial crisis in 2008 around the world. Europe, one of the most affected peripheral countries from global meltdown, has swiftly turned into the dismal of sovereign debt crisis. To rescue the credit and liquidity crunches in the banking system, the government had delivered the stimulus packages through credit channel to limit the likelihood of a new Great Depression. In consequence, the government received an extensive financial borrowing from economic agents such as International Monetary Fund (IMF) and European Centre Bank (ECB) and engendered a massive sovereign debt.

For instance, the Greek government has endowed troubled banks with financial assistance to stabilize the financial system and enhance economic activities. However, the enforcement of banking salvage and recession ultimately showed a hefty burden on the public finance and contributed to debt accumulation in Greece. In consequence, Greece is not the merely nation that radically dipped into the catastrophe of debt crisis, yet other euro zone members like Portugal, Ireland, Iceland, and Italy have also undergone a vividly soaring of debt level.

Since the prerequisite of countries condition to be a stylized fact for host countries to benefit from FDI, an incredible growth of sovereign debt in Europe recently has heightened the interest of this study towards the concern that if a positive link between FDI and economic growth is to be recognized, then how the debt level will eventually influence foreign investment in host countries? The conventional theoretical literature that links a high debt level to investment suggests that instability at the macroeconomic level seems to be unfavorable to foreign capital. According to debt overhang, for instance, a large accumulated debt stocks inherited by a country would extract a huge portion of the current output to creditors (Krugman, 1988). In consequence, a massive debt stocks would discourage the entrance of foreign capital due to a considerable debt service would increase the risk of restriction on profit and capital remittances (Nunnenkamp, 1991).

In addition, an incredible high debt payment creates uncertainty environment towards the policies implemented by the government since debt stocks could act as an implicit tax on future profit and production (Jayaraman and Choong, 2006). Hence, investors would be reluctant to engage more capital investment at present for the purpose of growing output since the additional output would be distorted by the government to finance debt service.

Recently, an intensive debate has arisen regarding FDIgrowth nexus in contingent with countries condition notably financial markets development, the degree of trade openness or human capital; however the absorptive capacity in the context of government debt has not been investigated specifically. To this end, this study attempts to examine the effects of debt on the nexus between FDI and growth in European countries. Thus far there is not aware of any literature explore to the impacts of debt on economic growth through the channel of FDI. To the best of our knowledge, this paper is unique in this respect.

This study is organized as follows: In Section 2, a brief review of the literature on FDI, debt and growth is presented. Section 3 describes the data and methodology being employed. The estimation results will be discussed in Section 4 and Section 5 is concluding remarks.

\section{LITERATURE REVIEW}

\section{FDI and Growth}

The position of FDI in economic growth has been a topical issue that debates intensively in the circles of literature on a diverse sharp contrast. De Mello (1997), Alguacil et al. (2008) and Kottaridi and Stengos (2010) postulated that FDI augmenting capital accumulation in host countries since it is a vital source to overcome capital-scarce economies through financing capital formation and complement domestic investment. On the contrary, Herzer (2012) claimed that FDI may not necessary increase the capital stocks of host countries if FDI flows are in the trait of mergers and acquisitions. Author reasoned that mergers and acquisitions across borders were typically a transfer of existing assets and resources from local firms to foreign firms. Hence FDI does not engender capital formation and economic growth. With capital diminishing return, moreover, FDI is merely contributed to a short-run growth in recipient countries.

Based on these skeptical views, Barro and Sala-i-Martin (1997), Borensztein et al. (1998), Chamarbagwala et al. (2000), Lee (2013) and Omri et al. (2014) overturned these phrases. According to the authors, the new products or processes initiated by foreign firms into domestic market may conducive the indigenous firms through the facilitation and diffusion of novel technology. The dissemination of novel technology could generate via the joint-venture between foreign and domestic firms, thus incorporate new technology directly into the production function. After noticing a product innovation, local entrepreneurs may strive to imitate the innovation wisely. In this context, technological spillovers created from FDI will offset the diminishing return of capital and keep the economic on the long term growth path.

In other state of affairs, Blomstrom and Kokko (1998), Borensztein et al. (1998), Batten and Vo (2009), and Omri et al. (2014) pointed out that FDI is a catalyst in raising the productivity and competitiveness of domestic industries. The most conceivable explanation of this affirmation could be attributed from the perspective that the advance technology being introduced by multinational firms into domestic market has been magnified the competition among indigenous and foreign firms. Thereby, a positive environment has been created in enhancing the production process of local firms with their existing or new technology. Nevertheless, Aitken and Harrison (1999), Driffield and Hughes (2003), Agosin and Machado (2005), Adams (2009) and Salike (2010) against this assertion and attested that FDI may generate a negative competition effect and crowding out the local firms from domestic market. The 
rationale is that even FDI raises the level of productivity and investment in host countries, nonetheless lower marginal costs due to firm-specific advantages from advance technologies and know-how management skills have attracted demand away from local firms.

The mixed results and inconclusive evidence on FDI-growth nexus has sparked off a series of recent studies shifted their focus in the context of absorptive capacity in host countries. According to Hermes and Lensink (2003), Alfaro et al. (2004), Alfaro et al. (2010) and Azman-Saini et al. (2010), a positive effect of FDI could be reached in conditional with a high level of financial development through the notion of technological change. Therefore, the positive effects of FDI on economic growth will only "kick in" after the financial market has been developed at a certain level of extent in host countries. Additionally, Borensztein et al. (1998), Xu (2000), Glass and Saggi (2002) and Yao and Wei (2007) documented achievement of a certain level of human capital is important for acquiring the positive effects of FDI. Authors asserted that the enhancement of technological progress was a key approach to achieve higher productivity since the absorptive capacity of recipient countries based on human capital has been improved.

\section{FDI and Debt}

Lin and Sosin (2001) emphasized that a moderate level of debt borrowing is likely to encourage growth by providing sufficient funds to the investment in infrastructure that is reluctant to be projected by private firms. The quality of physical infrastructure is an essential consideration for foreign companies, particularly the efficiency-seeking FDI in deciding the location choice for their platform production. With this in place, debt can improve the investment climate by funding the infrastructure in host countries (Kok and Ersoy, 2009; Bellak et al., 2009 and Mukim and Nunnenkamp, 2012).

On the other hand, another strand of scholar addressed that debt can hamper economic growth by discouraging the entrance of foreign capital. In the view of Krugman (1988), Karagol (2002) and Pattillo et al. (2002), the attempt to service high burden of debt accumulation and interest payment have threatened the ability of countries to meet its debt obligations. This critically discourages the inwards of foreign investment since potential investors are expected a substantial return from investment activities would be devoted to fulfill debt services in host countries.

Additionally, Bernake (1983) and Rodrik (1991) contended high debt burden creates uncertainty environment towards the change of actions and policies. According to authors, dipping down of domestic and foreign investments is chiefly triggered by unprecedented policy uncertainty. This driven rational investors to more favorable investment climate virtue of the risk aversion or irreversible of investment in debtor countries. Rodrik (1991) mentioned in order to repay debt stocks, government intends to actualize the policy in the form that might depressed investment and economic growth indirectly. The policies are probably printing money and hence generating the specter of hyperinflation, issuing domestic debt that shifting off the domestic investment, obliging indigenous banks to purchase and hold government debt. Therefore, the accumulation of a massive debt stocks is expected to result in foreign investors encircled with an uncertainty atmosphere towards the policy to meet the debt obligations.

In addition, Krugman (1988), Sachs (1989), Dooley and Helpman (1992) and Boyce (1992) shed lighted a raise in debt today must be accompanied by an equivalent increase taxes in future. This is accordance with the theorem of Ricardian equivalence where future tax revenues would use to finance debt issuance. Therefore, the investor may worry that the government will impose a significant tax on investment. Consequently, debt is likened a tax on profit earnings and leading the available returns that might use to funding investment are consumed by debt payment. Moreover, a substantial debt service cost might also increase the risk of restriction on capital remittances and expropriation on the profits from investment, hence scared off the potential foreign investors. Amid such uncertainty, investors are preferred to invest in quick return activities rather than a valuable long term investment.

\section{Methodology and Data}

\section{Model Specification}

This study aims to include three growth models for the purpose of investigating the sensitivity and stability of the models (Choong, 2012). Therefore, the long-run regressions are specified as below:

$$
\begin{aligned}
& \ln G D P_{i t}=\alpha_{1 i}+\kappa_{1 i} \ln D I_{i t}+\tau_{1 i} \ln T O_{i t}+\gamma_{1 i} \ln F D I_{i t}+\varepsilon_{1 i t} \\
& \ln G D P_{i t}=\alpha_{2 i}+\kappa_{2 i} \ln D I_{i t}+\tau_{2 i} \ln T O_{i t}+\gamma_{21 i} \ln F D I_{i t}+\delta_{2 i} \ln D E B T_{i t}+\varepsilon_{2 i t}
\end{aligned}
$$

$\ln G D P_{i t}=\alpha_{3 i}+\kappa_{3 i} \ln D I_{i t}+\tau_{3 i} \ln T O_{i t}+\gamma_{3 i} \ln F D I_{i t}+\delta_{3 i} \ln D E B T_{i t}+\rho_{3 i} \ln F D I * D E B T_{i t}+\varepsilon_{3 i t}$

Where GDP is real gross domestic product per capita, DI is domestic investment (as percentage of GDP) and TO is trade openness (as percentage of GDP). Moreover, FDI is net inflows of foreign direct investment (as percentage of GDP), $D E B T$ is gross government debt (as percentage of GDP) and $F D I^{*} D E B T$ is the interaction term between FDI and $D E B T$. In this case, $\varepsilon_{i t}$ is the error term and the $\alpha \mathrm{i}$ is used to account for the effects of country-specific. Furthermore, the cross-section units (countries) are denoted by $\mathrm{i}=1,2,3, \ldots, \mathrm{N}$ and $\mathrm{t}=1,2,3, \ldots, \mathrm{T}$ represents time periods. To alleviate the collinearity in Equation (3), this study employs the residual term that derived from Equation (4) as a proxy for interaction term, FDI*DEBT. The regression is specified as below:

$\ln D E B T^{*} F D I_{i t}=\beta_{i}+\beta_{2 i} \ln F D I_{i t}+\beta_{3 i} \ln D E B T_{i t}+\mu_{i t}$

Where $\beta_{i}$ represents country-specific effect and $\mu_{\text {it }}$ is white noise residual term. 


\section{Panel Cointegration Estimations}

This study investigates the growth model corresponding to the effects of debt through FDI spillovers based on panel econometric techniques. There are a few existing estimation methods that prevailing utilized in panel data models. At one extreme, the simple pooled method constraints intercepts and all slope parameters to be homogenous across groups. The second method consists of Random effects (RE), Fixed effects (FE) and Generalized Method of Moments (GMM) which allows intercepts to be freely independent across countries whilst imposing restriction of homogeneity on all slope coefficients. Under slope heterogeneity, however, Pesaran and Smith (1995) asserted that GMM are undermined by heterogeneity bias, particularly in small country samples and hence lead to an inconsistent and misleading longrun slope coefficient. On the other extreme, the Mean Group (MG) estimator proposed by Pesaran and Smith (1995) is less restrictive. MG has no constraint on all coefficients of countries since it is averaging separate ARDL regression coefficients for each cross unit in the panel. Therefore, this approach provides consistent estimates of the average parameters. Nevertheless, MG does not consider the stylized fact that some of the coefficients could be identical across countries. As an alternative, the Pooled Mean Group (PMG) introduced by Pesaran et al. (1999) is an intermediate estimator since it is positioning between the pooling (FE and GMM) and averaging (MG). This technique allows short run coefficients, speeds of adjustment (convergence rates), intercepts and error variances to vary but imposes longrun parameters to be common across groups. Pesaran et al. (1999) affirmed if the difference between long-run parameters of MG and PMG are homogenous, PMG estimator will provide consistent estimate parameters than MG estimator. As a consequence, Hausman test needs to be applied to examine the homogeneity of parameters.

Virtue of these concerns arise in preceding approaches, this study aims to utilize the PMG approach to examine the effects of debt on the nexus between FDI and growth. Therefore, the ARDL (p, $q, \ldots, q)$ dynamic panel specification proposed by for Equation (1), (2) and (3) are specified as follow:

$\ln G D P_{i t}=\mu_{i i}+\sum_{j=1}^{p} \eta_{i i, j} \ln G D P_{i, t-j}+\sum_{j=0}^{q} \omega_{i, j} \ln D I_{i, t, j}+\sum_{j=0}^{q} \varphi_{i l, j} \ln T O_{i, t-j}+\sum_{j=0}^{q} \vartheta_{i, j} \ln F D I_{i, t-j}+\varepsilon_{1 i t}$

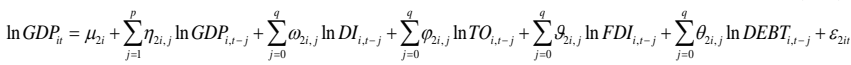

$\ln G D P_{i t}=\mu_{3 i}+\sum_{j=1}^{p} \eta_{3 i, j} \ln G D P_{i, t-j}+\sum_{j=0}^{q} \omega_{3 i, j} \ln D I_{i, t, j}+\sum_{j=0}^{4} \varphi_{3 i, j} \ln T O_{i, t, j}+\sum_{j=0}^{q} \vartheta_{3, i, j} \ln F D I_{i, t, j}$ $+\sum_{j=0}^{q} \theta_{3, i, j} \ln D E B T_{i, t-j}+\sum_{j=0}^{q} \psi_{3, i, j} \ln F D I * D E B T_{i, t-j}+\varepsilon_{3 i t}$

where $\mu_{i}$ denotes the fixed effects, $\eta_{i j}$ are scalars for the coefficients of lagged dependent variables and $\omega_{\mathrm{ij}}, \phi_{\mathrm{i}}, \vartheta_{\mathrm{ij}}, \theta_{\mathrm{ij}}$ and $\psi_{\mathrm{ij}}$ are $\mathrm{kx} 1$ coefficient vectors in Equation (1a), (2a) and (3a) respectively.

With PMG procedure, the Equation (1a), (2a) and (3a) can re-parameterization as an Error Correction Model (ECM):

$\Delta \ln G D P_{i t}=\phi_{1 i}\left(\ln G D P_{i, t-1}-\alpha_{1 i}-\kappa_{1 i} \ln D I_{i t}-\tau_{1 i} \ln T O_{i t}-\gamma_{1 i} \ln F D I_{i t}\right)+\sum_{j=1}^{p-1} \eta_{1 i, j}^{*} \Delta \ln G D P_{i, t-j}+\sum_{j=0}^{q-1} \omega_{1 i, j}^{*} \Delta \ln D I_{i, t-j}$ $+\sum_{j=0}^{q-1} \varphi_{1 i, j}^{*} \Delta \ln T O_{i, t-j}+\sum_{j=0}^{q-1} \vartheta_{1, j}^{*} \Delta \ln F D I_{i, t-j}+\mu_{1 i}+\varepsilon_{l i t}$

$\Delta \ln G D P_{i t}=\phi_{2 i}\left(\ln G D P_{i, t-1}-\alpha_{2 i}-\kappa_{2 i} \ln D I_{i t}-\tau_{2 i} \ln T O_{i t}-\gamma_{2 i} \ln F D I_{i t}-\delta_{2 i} \ln D E B T_{i t}\right)+\sum_{j=1}^{p-1} \eta_{2 i, j}^{*} \Delta \ln G D P_{i, t-j}$ $+\sum_{j=0}^{q-1} \omega_{2 i, j}^{*} \Delta \ln D I_{i, t-j}+\sum_{j=0}^{q-1} \varphi_{2 i, j}^{*} \Delta \ln T O_{i, t-j}+\sum_{j=0}^{q-1} \vartheta_{2 i, j}^{*} \Delta \ln F D I_{i, t-j}+\sum_{j=0}^{q-1} \theta_{2 i, j}^{*} \Delta \ln D E B T_{i,-j}+\mu_{2 i}+\varepsilon_{2 i t}$

$\Delta \ln G D P_{i t}=\phi_{3 i}\left(\ln G D P_{i, t-1}-\alpha_{3 i}-\kappa_{3 i} \ln D I_{i t}-\tau_{3 i} \ln T O_{i t}-\gamma_{3 i} \ln F D I_{i t}-\delta_{3 i} \ln D E B T_{i t}-\rho_{3 i} \ln D E B T^{*} F D I_{i t}\right.$ $+\sum_{j=1}^{p-1} \eta_{3 i, j}^{*} \Delta \ln G D P_{i, t-j}+\sum_{j=0}^{q-1} \omega_{3 i, j}^{*} \Delta \ln D I_{i, t-j}+\sum_{j=0}^{q-1} \varphi_{3 i, j}^{*} \Delta \ln T O_{i, t-j}+\sum_{j=0}^{q-1} \vartheta_{3 i, j}^{*} \Delta \ln F D I_{i, t-j}+\sum_{j=0}^{q-1} \theta_{3 i, j}^{*} \Delta \ln D E B T_{i, t-j}$ $+\sum_{j=0}^{q-1} \psi_{3 i, j}^{*} \Delta \ln F D I^{*} D E B T_{i, t-j}+\mu_{3 i}+\varepsilon_{3 i t}$

where $\phi_{1 i}=-\left(1-\sum_{j=1}^{p} \eta_{1 i, j}\right), \alpha_{1 i}=\mu_{1 i}, \kappa_{1 i}=\sum_{j=0}^{q} \omega_{1 i, j}, \tau_{1 i}=\sum_{j=0}^{q} \varphi_{1 i, j}$, $\gamma_{1 i}=\sum_{j=0}^{q} \vartheta_{1 i, j}$ based on Equation (1b); $\phi_{2 i}=-\left(1-\sum_{j=1}^{p} \eta_{2 i, j}\right)$, $\alpha_{2 i}=\mu_{2 i}, \kappa_{2 i}=\sum_{j=0}^{q} \omega_{2 i, j}, \tau_{2 i}=\sum_{j=0}^{q} \varphi_{2 i, j}, \gamma_{2 i}=\sum_{j=0}^{q} \vartheta_{2 i, j}, \delta_{2 i}=\sum_{j=0}^{q} \theta_{2 i, j}$ from Equation (2b) while Equation (3b) shows $\phi_{3 i}=-\left(1-\sum_{j=1}^{p} \eta_{3 i, j}\right), \alpha_{3 i}=\mu_{3 i}, \kappa_{3 i}=\sum_{j=0}^{q} \omega_{3 i, j}, \tau_{3 i}=\sum_{j=0}^{q} \varphi_{3 i, j}$, $\gamma_{3 i}=\sum_{j=0}^{q} \vartheta_{3 i, j}, \delta_{3 i}=\sum_{j=0}^{q} \theta_{3 i, j}, \rho_{3 i}=\sum_{j=0}^{q} \psi_{3 i, j}$.

The coefficients of the error correction term $\varphi_{\mathrm{i}}$ from Equation (1b), (2b) and (3b) represent the adjustment speed of GDP towards equilibrium in the long run after following an external shock. Therefore, the $\varphi_{\mathrm{i}}$ is expected to be negative and significant to ensure exists a long-run relationship between GDP and explanatory variables. $\kappa_{i}, \tau_{i}, \gamma_{i}, \delta_{i i}$ and $\rho_{i}$ denote the equilibrium relationships of government spending, trade openness, foreign direct investment, government debt and interaction term respectively with GDP. In contrast, $\eta_{i j}, \omega_{i j}, \varphi_{i j}, \vartheta_{i j}, \theta_{i j}$ and $\psi_{i j}$ are the short run coefficients relating to the past values of GDP and all regressors, respectively. Similarly o the previous equation, $\mu_{i t}$ implies fixed while $\varepsilon_{i t}$ is the disturbance or error term.

\section{Data Description}

To answer the question does government debt affect economic growth through the channel of FDI, this study examines the growth model by using the data from ten European countries where sovereign debt has increased drastically in recent years, namely: Greece, Italy, Portugal, Iceland, France, United Kingdom, Germany, Austria, Ireland and Spain. 
The data of all variables are retrieved from the World Development Indicator, World Bank with the exception of $D E B T$ is obtained from the OECD statistic. Besides, the sample period is spanning from 1990 to 2013 and all variables are transformed into log form. A short period of time is being employed by this study is mainly due to the availability of dataset. Moreover, the covering short period being used is more comparable with today's economic condition that happened in euro area countries (Baum et al., 2013).

\section{RESULTS ANALYSIS}

\section{Descriptive Statistics and Correlation Matrix}

Table 1 reports summary statistics of all variables based on two sub-samples. GDP, DI, FDI and FDI*DEBT, on average, depict a lower value after the onset of financial crisis globally in 2008 while DEBT and TO reveal a considerably higher level. A lower performance of GDP, domestic and foreign investments associated with a higher sovereign debt level could be attributed by the unprecedented financial disturbance and a massive introduction of fiscal stimulus packages in European countries. In sum, the difference in pre and post crises is in the expected direction. Table 2 displays the correlations between all variables in the equation. The correlation coefficients divulge a statistically significant positive association between GDP with all variables, except for domestic investment and debt are negatively correlated with GDP. Referring to the correlations between regressors, it is worth noting that none is exceed 0.8 . Moreover, Table 2 shows that the Variance Inflation Factor (VIF) for all explanatory variables is no more than 3. Therefore, the concern of collinearity would not be particularly relevant in this study.

\section{Results and Discussions}

The results of panel unit root tests from LLC, IPS and MW are reported in Table 3. It shows that the null hypothesis of panel non-stationary cannot be rejected in level form for all series, except $D I, F D I$, and $F D I^{*} D E B T$. After taking the first difference in these series, LLC, IPS and MW tests reject the presence of a unit root in favor of stationarity. In conclusion, all series are integrated of order 1, I(1) with the exception for $D I, F D I$, and $F D I{ }^{*} D E B T$ are stationary in level form.

Table 4 summarizes the test statistics for both within and between dimensions in Pedroni (1999) cointegration test. Apparently, the results provide an evidence of rejecting the null hypothesis of no cointegration in three models even not all the seven test statistics is significant. In a nutshell, the results of panel cointegration test indicate the presence of long-run relationship among the variables in Equation (1), (2) and (3), after taking the consideration of country-specific effect. The suggestions of cointegration relationship of all series in three equations entitle this study proceed with the cointegration estimation by using PMG approach. Table 5 contains the results of cointegration estimation for Equation (1b), (2b) and (3b). At first sight in PMG estimation, all longrun coefficients in Equation (1b) are econometrically and statistically significant at $1 \%$ level where the coefficient of FDI is 0.0447. This cointegration parameter indicates that FDI plays a positive role in European countries where higher foreign investment, by introducing more novel technologies and managerial expertise, would enhance economic growth in the long run. On the other hand, after including sovereign debt in Equation (2b), the long-run coefficients of FDI and $D E B T$ reveal a positive and negative magnitude respectively, which are broadly in line with the expected sign. Nevertheless, the interesting finding is that the coefficient of FDI in Equation (2b) is smaller than Equation (1b) once the sovereign debt has been considered. This result is accordance with the notion of Krugman (1988) and Sachs (1989) where higher debt tends to dwindle the positive externalities from foreign investment due to the instability of macroeconomics condition and government policies. Furthermore, this study intuitively investigates the indirect effects of sovereign debt on growth through the channel of FDI by including the interaction term- FDI*DEBT in Equation (3b).

Table 1: Descriptive Statistics

\begin{tabular}{|c|c|c|c|c|c|c|c|c|c|c|}
\hline & \multicolumn{5}{|c|}{ Pre-Crisis } & \multicolumn{5}{|c|}{ Post-Crisis } \\
\hline & Mean & Min & Max & SD & $\mathrm{Obs}$ & Mean & Min & Max & SD & $\mathrm{Obs}$ \\
\hline$\overline{\text { GDP }}$ & 34419.33 & 17922.40 & 58009.80 & 10843.68 & 50 & 34225.49 & 17919.40 & 57617.50 & 10567.29 & 50 \\
\hline TO & 75.1767 & 48.2895 & 152.0290 & 29.8930 & 50 & 83.6701 & 48.0246 & 191.3680 & 36.9590 & 50 \\
\hline DI & 16.9314 & 2.4766 & 30.4173 & 6.6641 & 50 & 15.6513 & 0.1635 & 26.8631 & 5.1578 & 50 \\
\hline FDI & 6.2139 & 0.2874 & 33.6747 & 7.9625 & 50 & 3.9040 & 0.1814 & 23.9241 & 5.0473 & 50 \\
\hline Debt & 54.7898 & 19.3780 & 110.5720 & 27.3740 & 50 & 78.3289 & 28.0010 & 169.7570 & 31.3745 & 50 \\
\hline FDI*DEBT & 0.0099 & -0.3864 & 1.1308 & 0.3558 & 50 & 0.0041 & -0.2136 & 0.6437 & 0.1392 & 50 \\
\hline
\end{tabular}

Notes: Data for pre-crisis started from 2003-2007 while post-crisis covered from 2008-2012.

Table 2: Correlation Matrix and Variance Inflation Factor

\begin{tabular}{|c|c|c|c|c|c|c|c|}
\hline & GDP & TO & DI & FDI & Debt & FD & VIF \\
\hline GDP & 1 & & & & & & -- \\
\hline TO & $0.5160 * * *$ & 1 & & & & & 2.46 \\
\hline DI & $-0.5034 * * *$ & $-0.4968 * * *$ & 1 & & & & 2.05 \\
\hline FDI & $0.4902 * * *$ & $0.6085 * * *$ & $-0.6912^{* * *}$ & 1 & & & 2.57 \\
\hline Debt & $-0.3746^{* * *}$ & $-0.1593 * * *$ & 0.0484 & $-0.2746^{* * * *}$ & 1 & & 1.17 \\
\hline FDI*DEBT & $0.1852^{* * *}$ & $0.5967 * * *$ & $-0.2079 * * *$ & $0.2535 * * *$ & $0.0752 * * *$ & 1 & 1.67 \\
\hline
\end{tabular}

Notes: ${ }^{* * *}$ indicates the rejection of the null hypothesis at $1 \%$ significance level and mean VIF is 1.98. 
The results of PMG estimation divulge that $F D I^{*} D E B T$ is negatively and statistically significant at 5\% level while FDI and DEBT are insignificant in the model. This finding is well entailed that the indirect effects of DEBT and FDI is dominant and leading over the direct effects. Accordingly, it has evident that the macroeconomic condition is vital in influencing the ability of host countries to benefit from FDI spillovers since sovereign debt has slowdown economic growth indirectly through FDI rather than directly impair the growth performance in the long term. The roots of negative $F D I^{*} D E B T$, in particular, could be stretched back to the depression of foreign investors' confidence level towards the instability of macroeconomics condition in European countries. Thereby, the decrease of FDI influx has lowered spillover effects and hence stifles economic growth.

In the context of long-run perspective, the sign of all coefficients are generally consistent in MG, PMG and DFE estimations, with the exception for $D I$ in Equation (2b) and FDI in Equation ( $3 b$ ), reveal a negative coefficient in MG and PMG estimations. However, Hausman test signifies that the restriction of long-run homogeneity cannot be rejected at even $10 \%$ level in three equations. In light of these findings, it is well asserted that the common long-run coefficients imposed by PMG are valid and hence it is preferable to MG estimation.

In the vein of long-run convergence, the error correction coefficients of PMG estimation are significantly negative in three equations. These results, most notably, have shed lighted the evidence in favor of cointegration relationship between the variables. In a nutshell, the speeds of convergence have signaled that GDP, on average, is corrected and restored towards its long-run equilibrium at a rate of $8.86 \%, 9.91 \%$ and $3.38 \%$ in every period, based on Equation (1b), (2b) and ( $3 b)$ respectively.

Furthermore, the average short run coefficients of PMG estimation document that FDI and DEBT are significant in Equation (1b) and (2b). With the presence of $F D I^{*} D E B T$ in Equation (3b), interestingly, the temporary impacts of FDI and $F D I^{*} D E B T$ are absent. This finding, thus, reflects the insight that the absence of $F D I^{*} D E B T^{\prime} s$ impacts have strengthened the results in Equation (3b) whereby government debt will impair the economic growth indirectly through FDI in the long run.

Table 3: Panel Unit Root Tests

\begin{tabular}{|c|c|c|c|c|c|c|}
\hline & \multicolumn{2}{|c|}{ Levin-Lin-Chu } & \multicolumn{2}{|c|}{ Im-Pesaran-Shin } & \multicolumn{2}{|c|}{ Maddalar $\mathrm{Wu}$} \\
\hline & Intercept & Intercept and trend & Intercept & Intercept and trend & Intercept & Intercept and trend \\
\hline \multicolumn{7}{|l|}{ Level } \\
\hline LGDP & -3.8726 & 3.4373 & -0.3321 & 3.8290 & 18.5884 & 13.0121 \\
\hline LTO & 0.1253 & -0.7999 & 1.5919 & -0.7647 & 12.5926 & 22.3422 \\
\hline LDI & $-1.4813^{*}$ & $-1.0383^{*}$ & $-2.0550 * *$ & $-2.4052 * * *$ & $42.2927 * * *$ & $50.0576 * * *$ \\
\hline LFDI & $-2.9185 * * *$ & $-3.5204 * * *$ & $-3.5670 * * *$ & $-4.5095 * * *$ & $49.7703^{* * *}$ & $59.8708 * * *$ \\
\hline LDEBT & -1.4709 & 0.4742 & -0.7810 & 0.8559 & 27.3291 & 9.7314 \\
\hline FDI*DEBT & $-1.7279 * *$ & -0.3817 & $-2.7844 * * *$ & -1.1178 & $42.0009 * * *$ & $35.5007 * * *$ \\
\hline \multicolumn{7}{|c|}{ First Difference } \\
\hline LGDP & $-3.5370 * * *$ & $-4.8101^{* * * *}$ & $-3.5739 * * *$ & $-3.2755^{* * * *}$ & $48.8844 * * *$ & $44.6969 * * *$ \\
\hline LTO & $-11.7715 * * *$ & $-8.9108 * * *$ & $-9.9181 * * *$ & $-7.7105 * * *$ & $119.160 * * *$ & $86.4814^{* * * *}$ \\
\hline LDI & -- & -- & -- & -- & - & - \\
\hline LFDI & - & - & - & -- & -- & - \\
\hline LDEBT & $-4.1480 * * *$ & $-3.5421 * * *$ & $-3.4608 * * *$ & $-2.2913 * * *$ & $44.0337 * * *$ & $32.6543 * *$ \\
\hline FDI*DEBT & - & - & - & - & - & - \\
\hline
\end{tabular}

Notes: ${ }^{* * *},{ }^{* *}$ and ${ }^{*}$ indicate the rejection of the null hypothesis at $1 \%, 5 \%$ and $10 \%$ significance levels, respectively.

Table 4: Pedroni Cointegration Tests

\begin{tabular}{lccc}
\hline Equation & 1 & 2 & 3 \\
\hline Within dimension & $2.1450 * *$ & $10.9443^{* * * *}$ & $9.4155^{* * *}$ \\
\hline Panel v-statistic & 2.0694 & 2.0634 & 2.5906 \\
Panel p-statistic & 1.7243 & -0.4640 & 0.1340 \\
Panel PP-statistic & 1.4573 & $-1.4041^{*}$ & $-1.0944^{*}$ \\
Panel ADF-statistic & & & 3.7257 \\
Between dimension & 2.5699 & 3.1569 & 0.4214 \\
Group v-statistic & -0.1261 & -0.0747 & -0.8235 \\
Group PP-statistic & -0.6047 & -0.6482 & \\
Group ADF-statistic & & & \\
\hline
\end{tabular}

Notes: ${ }^{* * *},{ }^{* *}$ and ${ }^{*}$ indicate the rejection of the null hypothesis of no cointegration at $1 \%, 5 \%$ and $10 \%$ significance levels, respectively. 
Table 5: Panel Cointegration Estimations

\begin{tabular}{|c|c|c|c|c|c|c|c|c|c|}
\hline \multirow[t]{2}{*}{ Equation } & \multicolumn{3}{|c|}{$1 b$ ARDL $(2,1,1,1)$} & \multicolumn{3}{|c|}{$2 \mathrm{~b}$ ARDL $(1,2,1,1,1)$} & \multicolumn{3}{|c|}{ 3b ARDL $(1,2,3,1,1,1)$} \\
\hline & $\mathrm{MG}$ & PMG & $\mathrm{DFE}$ & MG & PMG & $\mathrm{DFE}$ & MG & PMG & DFE \\
\hline \multicolumn{10}{|c|}{ Long run coefficients } \\
\hline LTO & $0.4369 * *$ & $0.4986 * * *$ & $0.0447 * * *$ & $0.6586 * *$ & 0.1050 & $0.5895 * * *$ & $0.5130 * * *$ & $0.9033 * * *$ & $0.6871 * * *$ \\
\hline LDI & 0.2023 & $0.3340 * * *$ & $0.1567 * *$ & 0.7099 & $-0.0803^{*}$ & 0.0264 & $0.5888 * *$ & $0.9113 * * *$ & * 0.0975 \\
\hline LFDI & $0.0988 * *$ & $0.0447 * * *$ & $0.0909 * * *$ & 0.0683 & $0.0318 * * *$ & 0.0225 & -0.0346 & -0.0560 & 0.0082 \\
\hline LDEBT & & & & -0.0121 & $-0.1859 * * *$ & $-0.2799 * * *$ & -0.0883 & -0.1764 & $-0.3454 * * *$ \\
\hline LFDI*DEBT & & & & & & & -0.9727 & $-2.1140 * *$ & -0.1361 \\
\hline \multicolumn{10}{|c|}{ Convergence coefficient } \\
\hline$\phi_{\mathrm{i}}$ & $-0.1860 * * *$ & $-0.0886 * * *$ & $-0.0967 * * *$ & $-0.2098 * * *$ & $-0.0991 * *$ & $-0.0980 * * *$ & -0.2267 & $-0.0338 *-$ & $-0.1025 * * *$ \\
\hline \multicolumn{10}{|c|}{ Short run coefficients } \\
\hline$\Delta \mathrm{LTO}$ & 0.0083 & 0.0220 & 0.0148 & $0.0905 * * *$ & $0.1601 * * *$ & $0.1334 * * *$ & -0.0097 & $0.1387 * * *$ & * $0.1104 * * *$ \\
\hline$\Delta \mathrm{LDI}$ & 0.0383 & $0.0487^{*}$ & -0.0055 & 0.0233 & $0.0609 * * *$ & -0.0023 & -0.0751 & -0.0148 & -0.0230 \\
\hline$\triangle \mathrm{LFDI}$ & 0.0006 & $0.0061 * *$ & -0.0016 & 0.0028 & $0.0051^{*}$ & -0.0006 & -0.0140 & -0.0063 & $0.0049 * *$ \\
\hline$\triangle \mathrm{LDEBT}$ & & & & $-0.1113 * * *$ & $-0.1276 * * *$ & $-0.1054 * * *$ & $-0.1999 *$ & $-0.109 * * *$ & $-0.0875 * * *$ \\
\hline$\triangle \mathrm{LFDI} * \mathrm{DEBT}$ & & & & & & & -0.2829 & -0.1650 & $0.0768 * * *$ \\
\hline$\Delta^{2} \mathrm{LGDP}$ & $0.3162 * * *$ & $0.2605^{* * * *}$ & $0.4249 * * *$ & & & & & & \\
\hline$\Delta^{2} \mathrm{LTO}$ & & & & -0.0200 & $-0.0450 * *$ & -0.0078 & 0.0568 & -0.0117 & -0.0003 \\
\hline$\Delta^{2} \mathrm{LDI}$ & & & & & & & 0.0476 & 0.0255 & 0.0149 \\
\hline$\Delta^{3} \mathrm{LDI}$ & & & & & & & -0.0063 & -0.0030 & -0.0028 \\
\hline Hausman test & & & 0.54 & & & 4.34 & & & 2.27 \\
\hline Observation & & & 208 & & & 208 & & & 208 \\
\hline
\end{tabular}

Notes: ${ }^{* * *},{ }^{* *}$ and ${ }^{*}$ indicate the rejection of the null hypothesis of no cointegration at $1 \%, 5 \%$ and $10 \%$ significance levels, respectively. The appropriate lag order for $\operatorname{ARDL}(p, q, \ldots, q)$ in each equation is selected based on Akaike information criterion.

\section{Concluding Remarks and Policy Implications}

With the rise of globalization, foreign investment has been increasingly important in industrialized and developing countries as a strategy to enhance economic growth and development. With the influx of FDI, it is not merely improve the productivity of a particular country through novel technology and knowledge expertise, yet also infuse capital into the market. Consequently, the government policies that aim to attract foreign capital have been implemented through tax and fiscal incentives, availability of high-skilled labor force, better infrastructure, loosing profit repatriation and efficient administrative procedures.

Even so, the beneficial of FDI is still far from a conclusion and yet remains a controversial issue in the context of policy circle. Moreover, the contribution of FDI is highly unparallel across countries based on the local condition of host countries. In this respect, this study has provided new evidence on this concern in the context of European countries that have endured a remarkable growth of government debt after a great financial upheaval in 2008-2009.

By utilizing the PMG estimation, by and large, the empirical results unveiled that FDI is an essential catalyst in facilitating and enhancing the economic growth. Even so, growth performance has been drag out and decelerated indirectly with the presence of government debt through FDI. This finding, nevertheless, is in line with the hypothesis of "crowding out effects" where over borrowing of public finance would crowd out the private investment, hence shrinking private capital stocks and output level of the economy in the long run.

In a nutshell, FDI is vital to encourage the economic growth of European countries. Therefore, the government should endeavor to attract foreign investment to tackle and revive the economy from financial and debt crises. However, the stability of macroeconomic is playing a crucial part towards the impacts of FDI on economic growth virtue of an enormous debt burden creates the unattractive investment climate to foreign investors. For this reason, the government should reform and enhance the investment framework through an effective and sound debt management policy. With this in place, a welldesigned debt management mechanism would not merely reduce the financing cost of public expenditure, but also restore the confidence level of foreign investors through a stable debt level and investment climate.

\section{REFERENCES}

Adams, S. (2009) "Foreign direct investment, domestic investment, and economic growth in Sub-Saharan Africa", Journal of Policy Modeling, Vol.31 No.6, pp. 939-949.

Agosin, M. R. and Machado, R. (2005) "Foreign investment in developing countries: Does it crowd out in domestic investment?", Oxford Development Studies, Vol. 33 No.2, pp.149-162.

Aitken, B. J. and Harrison, A. (1999) "Do domestic firms benefit from foreign direct investment? Evidence from Venezuela", American Economics Review, Vol.89 No.3, pp.605-618.

Alfaro, L., Chanda, A., Kalemli-Ozcan, S. and Sayek, S. (2004) "FDI and economic growth: the role of local financial markets", Journal of International Economics, Vol.64 No.1, pp.89-112. 
Alfaro, L., Chanda, A., Kalemli-Ozcan, S. and Sayek, S. (2010) “Does foreign direct investment promote growth? Exploring the role of financial markets on linkages", Journal of Development Economics, Vol.91 N0.2, pp.242-256.

Alguacil, M., Cuadros, A. and Orts, V. (2008) "EU enlargement and inward FDI", Review of Development Economics, Vol.12 No.3, pp.594-604.

Alguacil, M., Cuadros, A. and Orts, V. (2011) "Inward FDI and growth: The role of macroeconomics and institutional environment", Journal of Policy Modeling, Vol.33 No.3, pp.482-496.

Azman-Saini, W.N.W., Law, S.H. and Ahmad, A. H. (2010) “FDI and economic growth: New evidence on the role of financial markets", Economic Letters, Vol.107 No.2, pp.211-213.

Barro, R. J. and Sala-i-Martin, X. (1997) "Technology diffusion, convergence and growth. Journal of Economic Growth", Vol.2 No.1, pp.1-26.

Batten, J. A. and Vo, X. V. (2009) "An analysis of the relationship between foreign direct investment and economic growth", Applied Economics, Vol.41 No.13, pp.1621-1641.

Baum, A., Checherita-Westphal, C. and Rother, P. (2013) "Debt and growth: New evidence for the euro area", Journal of International Money and Finance, Vol.32 No. C, pp.809-821.

Bellak, C., Leibrecht, M. and Damijan, J. P. (2009) "Infrastructure endowment and corporate income taxes as determinants of foreign direct investment in Central and Eastern European countries", The World Economy, Vol.32 No.2, pp.267-290.

Bernake, B. S. (1983) "Irreversibility, uncertainty, and cyclical investment", The Quarterly Journals of Economics, Vol.98 No1, 85-106.

Bevan, A. A. and Estrin, S. (2004) "The determinants of foreign direct investment into European transition economies", Journal of Comparative Economics, Vol.32 No.4, pp.775-787.

Blomstrom, M. and Kokko, A. (1998) "Multinational corporations and spillovers", Journal of Economic Surveys, Vol.12 No.3, pp.247-277.

Borensztein, E., De Gregorio, J. and Lee, J.W. (1998) "How does foreign direct investment affect economic growth?", Journal of International Economics, Vol.45 No.1, pp.115-135.

Boyce, J. K. (1992) "The revolving door? External debt and capital flight: A Philippine case study", World Development, Vol.20 No.3, pp.335-349.

Chamarbagwala, R., Ramaswamy, S. and Wunnava, P.V. (2000) "The role of foreign capital in domestic manufacturing productivity: Empirical evidence from Asian Economies", Applied Economics, Vol.32 No.4, pp.393-398.

Choong, C. K. (2012) "Does domestic financial development enhance the linkages between foreign direct investment and economic growth?", Empirical Economics, Vol.42 No.3, pp.819-834.

De Mello, L. R. (1997) "Foreign direct investment in developing countries and growth: A selective survey", Journal of Development Studies, Vol.34 No.1, pp.1-34.

Di Mauro, F. (1999) "The effects of economic integration on FDI flows: An empirical analysis and comparison with trade", Center for European Policy Studies Document Paper, No.134.

Dooley, M. P. and Helpman, E. (1992) "Tax credits for debt reduction", Journal of International Economics, Vol.32 No.1-2, pp.165-177.

Driffield, N. and Hughes, D. (2003) "Foreign and domestic investment: Regional development or crowding out", Regional Studies, Vol.37 No.3, pp.277-288.

Glass, A. J. and Saggi, K. (2002) "Multinational firms and technology transfer", The Scandinavian Journal of Economics, Vol.104 No.4, pp.495-513.

Hansen, H. and Rand, J. (2006) "On the causal links between FDI and growth in developing countries", The World Economy, Vol.29 No.1, pp.21-41.

Hermes, N. and Lensink, R. (2003) "Foreign direct investment, financial development and economic growth", Journal of Development Studies, Vol.40 No.1, pp.142-163.

Herzer, D. (2012) "How does foreign direct investment really affect developing countries' growth?", Review of International Economics, Vol.20 No.2, pp.396-414.
Jayaraman, T. K. and Choong, C. K. (2006) "Public debt and economic growth in the South Pacific Islands: A case study of Fuji", Journal of Economic Development, Vol.31 No.2, pp.107-121.

Jost, T. (2010) "Inward FDI in Germany and its policy context". Available

from: http:/ /academiccommons.columbia.edu/catalog/ac:128862

Karagol, E. (2002) "The causality analysis of external debt service and GNP: The case of Turkey", Central Bank Review, Vol.1, pp.39-64.

Kok, R. and Ersoy, A. B. (2009) "Analyses of FDI determinants in developing countries", International Journal of Social Economics, Vol.35 No.1, pp.105-123.

Kottaridi, C. and Stengos. T. (2010) "Foreign direct investment, human capital and non-linearities in economic growth", Journal of Macroeconomics, Vol.32 No.3, pp.858-871.

Krugman, P. R. (1988) "Financing vs. forgiving a debt overhang", Journal of Development Economics, Vol.29 No.3, pp.253-268.

Lee, J. W. (2013) "The contribution of foreign direct investment to clean energy use, carbon emissions and economic growth", Energy Policy, Vol.55, pp.483-489.

Lin, S. L. and Sosin, K. (2001) "Foreign debt and economic growth", Economics of Transition, Vol.9 No.3, pp.635-655.

Liu, Q. and Qiu, L. (2014) "Labor training and foreign direct investment", Review of International Economics, Vol.22 No.1, pp.151-166.

Mukim, M. and Nunnenkamp, P. (2012) "The location choices of foreign investors: A district-level analysis in India", The World Economy, Vol.35 No.7, pp.886-918.

Nunnenkamp, P. (1991) “Developing countries' attractiveness for FDI, debt overhang and sovereign risk as major impediments?", The Pakistan Development Review, Vol.30 No.4, pp.1145-1158.

OECD. (1994a) "OECD reviews of foreign direct investment: Portugal", Organization for Economic Co-operation and development.

OECD. (1994b) "OECD reviews of foreign direct investment: Italy", Organization for Economic Co-operation and development.

Omri, A., Nguyen, D. K. and Rault, C. (2014) "Causal interactions between $\mathrm{CO} 2$ emissions, FDI, and economic growth: Evidence from dynamic simultaneous-equation models", Economic Modelling, Vol.42 No.C, pp.382-389.

Pattillo, C., Poirson, H. and Ricci, L.A. (2002) "External debt and growth", Finance and Development, Vol.39 No.2, pp.32-35.

Pedroni, P. (1999) "Critical values for cointegration tests in heterogeneous panels with multiple regressors", Oxford Bulletin of Economics and Statistics, Vol.61 No.1, pp.653-670.

Pesaran, M. H. and Smith, R. (1995) "Estimating long-run relationships from dynamic heterogeneous panels", Journal of Econometrics, Vol.68 No1, pp.79-113.

Pesaran, M. H., Shin, Y. and Smith, R. P. (1999) "Pooled mean group estimation of dynamic heterogeneous panels", Journal of American Statistical Association, Vol.94 No.446, pp.621-634.

Roberts, B. M., Thompson, S. and Mikolajczyk, K. (2008) "Privatization, foreign acquisition and the motives for FDI in Eastern Europe", Review of World Economics, Vol.144 No.3, pp.408-427.

Rodrik, D. (1991) "Policy uncertainty and private investment in developing countries", Journal of Development Economics, Vol.36 No.2, pp.229-242.

Sachs, J.D. (1989) "The debt overhang of developing countries", in Calvo, G. et al (Eds.), Debt stabilization and development: Essay in memory of Carlos Diaz-Alejandro, Basil Blackwell, Oxford, pp.80-102.

Salike, N. (2010) "Investigation of the "China effect" on crowding out of Japanese FDI: An industry-level analysis (1990-2004)", China Economic Review, Vol.21 No.4, pp.582-597.

$\mathrm{Xu}, \mathrm{B}$. (2000) "Multinational enterprises, technology diffusion, and host country productivity growth", Journal of Development Economics, Vol.62 No.2, pp.477-493.

Yao, S. and Wei, K. (2007) "Economic growth in the presence of FDI: The perspective of newly industrializing economies", Journal of Comparative Economics, Vol.35 No.1, pp.211-234.

$-0--$ 